\title{
A Reflection of the Struggle for Individual Freedom in Nineteenth- Century Russia in the Life and Work of V.F. Raevskogo «The First Decembrist»
}

\section{Yunkina Anna Aleksandrovna ${ }^{1}$}

Teacher of Russian language and literature, Municipal Budgetary General Education Institution "Secondary School №11" MBOU "SOSH 11" the city of Stary Oskol

(Belgorod region), Staryy Oskol, Russia.

(date of receiving: February, 2019; date of acceptance: August, 2019)

\begin{abstract}
The study Goal was to recreate the image of the tragic and heroic personality of the poet-Decembrist V.F. Raevsky, analyzing books dedicated to his life, to get acquainted with the history of the poems. The life-tragedy of the V.F. Raevskogo is that he is, sentenced by a military court to death for free-thinking, spent five years in the castle dungeons, awaiting execution, and after its cancellation - more than forty years in Siberian exile. The heroism of "the first Decembrist" is that even in this hopeless situation, he survived, not broken, fought valiantly for life for the truth. In exile, Vladimir Fedoseevich Raevsky was taught to read and write peasant children. In Siberia, he continued to write poetry. In the center of his Rejewski - way "singer in prison", unyielding fighter for his ideals, not bowed "ramen head" or to the people or to fate. In spite of all the blows of the rock, V.F. Raevsky did not lose heart, remained true to his ideals and values to the end.
\end{abstract}

Keywords: V.F. Raevsky, Decembrists, Link, Poem, Noble Family, Teaching Activities, Destiny.

1.E-mail: 1anna_76@mail.ru 


\title{
Отражение борьбы за свободу личности в России XIX века в жизни и творчестве В.Ф. Раевского - «первого декабриста»
}

\author{
Юнкина Анна Александровна ${ }^{1}$ \\ Учитель русского языка и литературы муниципального бюджетного \\ общеобразовательного учреждения \\ «Средняя общеобразовательная школа №11» (МБОУ «СОШ №11» города \\ Старый Оскол, \\ Старый Оскол (Белгородской области), Россия. \\ (дата получения: февраль 2019 г.; дата принятия: август 2019 г.)
}

\begin{abstract}
Аннотация
Цель исследования - воссоздать образ трагической и героической личности поэта-декабриста В.Ф. Раевского, проанализировав книги, посвящённые его судьбе.

Жизненная трагедия В.Ф. Раевского состоит в том, что он, приговоренный военным судом к смертной казни за вольнодумство, провёл пять лет в крепостных застенках, ожидая исполнения приговора, а после его отмены - более сорока лет в сибирской ссылке. Героизм «первого декабриста» в том, что даже в этой безнадёжной ситуации он выстоял, мужественно боролся за правду.

Находясь в ссылке, Владимир Федосеевич Раевский учил грамоте крестьянских детей. Он женился на крещёной бурятке Евдокии Моисеевне Середкиной, успешно хлебопашествовал, огородничал: устроил парники, выращивал арбузы и дыни; купил мельницу, завел лошадей. В Сибири продолжал писать стихи. В центре творчества Раевского - образ «певца в темнице», непреклонного борца за свои идеалы, не склонившего «рамен с главою» ни перед людьми, ни перед судьбою.
\end{abstract}

Ключевые слова: В.Ф. Раевский, декабрист, ссылка, стихотворения, дворянский род, педагогическая деятельность, судьба.

1. E-mail: 1anna_76@mail.ru 


\section{Введение}

Формулировка проблемы. Имя «первого декабриста» В.Ф. Раевского недостаточно известно современной молодёжи. Ни того, что его именем названа улица в Старом Осколе, ни музея в селе Богословка под Губкином недостаточно для популяризации незаурядной, талантливой личности, обладавшей невероятной силой духа. Поэтому актуальность исследования заключается в том, что оно предлагает познакомиться с неизвестными страницами жизни нашего выдающегося земляка. Цель исследования воссоздать образ трагической и героической личности поэта-декабриста. Для достижения цели поставлены следующие задачи: проанализировать книги, посвящённые судьбе В.Ф. Раевского, познакомиться с историей создания стихотворений.

Краткий обзор используемой литературы и источников: краткая информация о жизни В.Ф. Раевского содержится в «Белгородской энциклопедии». Александр и Николай Крупенковы написали книгу «Судьба декабриста» в остросюжетном публицистическом жанре на основе использования архивных документов, обнаруженных авторами в переписке семьи Раевских и публикующихся впервые. Книга А.Н. Крупенкова «Братья Раевские» посвящена В.Ф. Раевскому и его братьям, людям неординарным, оставившим след в истории страны. При подготовке очерков использованы ранее неопубликованные письма родственников В.Ф. Раевского, обнаруженные в Центральном государственном архиве Октябрьской революции. Изучению биографии В.Ф. Раевского посвящена книга Натана Эйдельмана «Необыкновенная жизнь декабриста Раевского». Большую историческую и научную ценность представляет целиком состоящая из документов книга «Воспоминания В.Ф. Раевского», подготовленная к печати исследователемлитературоведом М.К. Азадовским. Первым же биографом В.Ф. Раевского стал П.Е. Щеголев, посвятивший жизнь изучению фактов биографии А.С. Пушкина. 
Он видел в Раевском лишь типичнейшего представителя вольнодумства Александровской эпохи, не выделявшегося сколько-нибудь заметно из среды других деятелей того времени. Невысоко ценил первый биограф Раевского его поэтическое творчество; его стихи имели, по мнению Щеголева, лишь историко-литературное значение. Благодаря исследованиям и публикациям Л. Сперанской, В.Г. Базанова и П.С. Бейсова фонд сочинений Раевского обогатился ценнейшими материалами: стихотворения, письма, наброски художественных отрывков в прозе, официальные заявления и протесты, политические и публицистические трактаты, автобиографические наброски и записки. В свете этих материалов и исследований Раевский предстает перед нами как выдающийся представитель начальной поры революционного движения, замечательный пропагандист и организатор, незаурядный поэт, талантливый и блестящий писатель-публицист.

Предмет исследования: личность, политические взгляды, семья В.Ф. Раевского. Объект исследования: воспоминания, письма, исследовательская литература, посвящённая сложной судьбе В.Ф. Раевского. Методы исследования: чтение произведений, изучение литературы по теме. Гипотеза: Трагедия В.Ф. Раевского в том, что он, приговоренный военным судом к смертной казни за вольнодумство, провёл долгие пять лет в крепостных застенках, ожидая исполнения приговора, а после его отмены - более сорока лет в сибирской ссылке. А героизм «первого декабриста», как назвали его позже, состоит в том, что даже в этой, казалось бы, безнадёжной ситуации он выстоял, не сломался, мужественно боролся за жизнь, за правду, как он её понимал, и в итоге, одержал победу над своими мучителями.

\section{Основная часть}

Чем может быть интересна современному читателю личность Владимира Федосеевича Раевского? Чем прославился человек, на родине которого, в селе 
Богословка Губкинского городского округа, к 200-летию со дня его рождения, 8 апреля 1995 года, открыт и ныне действует дом-музей? Село, в котором расположен музей, раньше называлось слободой Хворостянкой. В конце XVIII века она относилась к Старооскольскому уезду Курской губернии. Именно здесь 28 марта (8 апреля) 1795 года родился первый декабрист, хороший друг «солнца русской поэзии» А.С. Пушкина, поэт, публицист, участник Бородинского сражения Владимир Федосеевич Раевский. Он принадлежал к старинному дворянскому роду, имевшему, в том числе, и собственный герб. В XVIII в. слобода Хворостянка была подарена Александре Андреевне Фениной (матери Владимира Федосеевича) как приданое. Её муж, Раевский Федосей Михайлович, построил здесь одноэтажный дом, с колоннами и стрельчатыми окнами, посадил фруктовый сад и липовую аллею. В этой семье и родился будущий декабрист Раевский В.Ф. Его родители построили Андреевскую церковь. В музее хранится камень из основания церкви, на котором написано: «1804 года мая 18 дня усердием Федосея Михайловича и Александры Андреевны Раевских». Сохранил этот камень краевед, житель села Хворостянка, учитель Шаталов.

А в начале XIX в. приезжает второй Раевский - Владимир Гаврилович и строит дом на участке, который был подарен его жене Шеховской. Двухэтажный дом с фруктовым садом, липовыми аллеями и с привезёнными из Америки каштанами начали строить в 20-х гг. XIX в. Часть аллеи и два каштана сохранились до наших дней. В Хворостянке помнят, что Раевские были добрыми помещиками и всегда помогали крестьянам в трудное время, давали продукты, если к ним обращались. Вероятно, именно своей добротой, интеллигентностью, культурой поведения запомнились Раевские.

Последним Раевским, жившим в этом доме, был двоюродный племянник Владимира Федосеевича - Николай. Начавшаяся в XX веке борьба с местными богатеями не коснулась помещика Раевского Н.В., так как крестьяне не имели 
к нему никаких претензий: он был добр к ним, откликался на просьбы. Поэтому он прожил в селе до 1929 г., а потом, передав дом под школу, уехал в Ленинград к детям. Школа начала свою работу с 1930 г. по решению Райисполкома. Сначала это была ШКМ (школа крестьянской молодёжи), а с 1939 г.- средняя школа. С 1973 по 1995 г. дом стал превращаться в развалины. В 2013 году дворянскую усадьбу отреставрировали. Сейчас дом Раевского памятник архитектуры регионального значения. В нём под одной крышей расположились музей, рассказывающий о жизни первого декабриста, библиотека, детская музыкальная школа и Дом ремёсел.

В родовом поместье прошли первые восемь лет жизни Владимира Федосеевича, сюда он приезжал в 1858 году, после амнистии, подышать воздухом родных мест и поклониться могилам отца, матери, четырёх братьев и двух сестёр.

\footnotetext{
Пришлец! Здесь родина твоя -

Впервые светлая заря

Здесь взор твой озарила

Здесь колыбель твоя была

И праотцов твоих могила.
}

Истоки характера человека нужно искать в его детстве. Для получения образования Владимира Раевского отправляют из родных мест в Москву, где он восемь лет проводит в благородном пансионе при Московском университете, существовавшем на взносы состоятельных родителей. В том же московском пансионе обучались В.А. Жуковский, А.С. Грибоедов, М.Ю. Лермонтов. Выбор такого учебного заведения свидетельствует о том, что отец Владимира придавал огромное значение хорошему образованию детей, открывающему прекрасные жизненные перспективы, и не жалел для этого ни сил, ни средств. Годовая плата при поступлении в пансион составляла 750 
рублей. Если родители не обеспечивали детей учебными книгами, то за право пользоваться учебниками платили. Желающие обучиться игре на фортепиано или верховой езде также оплачивали уроки за свой счёт. (За обучение игре на скрипке и флейте плата не взималась). При поступлении воспитанники дарили пансиону серебряные ложки, простые ножи и вилки. Не трудно представить, сколько средств потребовалось Федосею Михайловичу Раевскому на содержание в благородном пансионе трёх сыновей. Но не только о просвещении родных детей заботился Федосей Михайлович. Село Богословка было в числе самых просвещённых населенных пунктов края, потому что помещики Раевские стремились охватить обучением всех детей своей округи, построив для них школы.

Режим в благородном пансионе резко отличался от домашнего, но Владимир быстро освоился. Раевский готов был соблюдать справедливый порядок. В пять часов утра, едва в коридорах раздавался звонок, воспитанники были на ногах. И с этого момента их время было подчинено строгому распорядку: завтрак, занятия в классах, обед, приготовление уроков на завтра. Учёба чередовалась с играми, развлечениями. А ровно в девять вечера все были в кроватях, отходили ко сну. Видимо, именно эта привычка к порядку, умение грамотно и с пользой распределять время, и помогли Раевскому не сломаться в годы испытаний тюремным заключением и ссылкой...

Жили пансионеры в общем корпусе. Только для отличных и полуотличных учеников выделялись отдельные комнаты или горницы. За занятиями, играми, поступками и общением между собой, за явкой в классы и столовую, за здоровьем и опрятностью учеников наблюдали комнатные надзиратели, неотлучно находящиеся при воспитанниках.

К концу обучения Раевский обладал глубокими познаниями в области отечественной и мировой истории и литературы, географии, в совершенстве овладел французским и немецким языками. У Владимира в пансионе были 
любимые учителя, которые прививали своим ученикам понятия доброты, справедливости, человеческого достоинства и подлинного благородства. Годы учёбы стали хорошей школой умственного и нравственного развития. Уже тогда у Владимира начала складываться собственная точка зрения на некоторые явления жизни, которая отличалась от общепринятой, в частности, от той, которой придерживались отец и родственники. В одном из своих позднейших писем, вспоминая время учения в пансионе, Раевский писал сестре Вере: «Любил ли меня отец наравне с братьями Александром и Андреем - я не хотел знать, но что он верил мне более других братьев, надеялся на меня одного, - это я знал. Он хорошо понимал меня и в письмах своих, вместо эпиграфа, начинал: «Не будь горд, гордым Бог противен»; в моих ответах я начинал: «Унижение паче гордости»... Я воспитывался с братьями вместе, братья не были дружны между собой, но оба они искренно любили меня. И когда мать наша посылала нам деньги на конфекты и пансион, и всегда мне менее, нежели каждому из них, - они всегда делились поровну и как бы стыдились за мать» (Натан Эйдельман). Первым ударом, обрушившимся на Владимира, стала смерть матери: одиннадцать детей осиротели, когда в 1810 году от чахотки умерла мать Александра Андреевна Раевская.

В годы учёбы в благородном пансионе Владимир был близок со старшим братом Александром, тем тяжелее стала его безвременная кончина от чахотки. Боль утраты выразил Раевский в стихотворении «Элегия»:

Раздался звон глухой... Я слышу скорбный глас,

Песнь погребальную вдали протяжным хором,

И гроб, предшествуем бесчувственным собором.

Увы! То юноша предвременно угас!

Неумолимая невинного сразила

Зарею юных дней 
И кров таинственный, неведомый открыла

Для горести отца, родных его, друзей.

В автобиографическом письме к В. Ф. Поповой от 21 мая 1868 г. читаем: «Насколько любил я сестер моих — и Наталья, и Александра очень хорошо знали, - когда в Петербурге с Петербургской стороны в Смольный монастырь, зимою, в 30 градусов мороза, в легкой шинельке сверх мундира, в кивере и в холодных сапогах, я ходил пешком, чтобы только повидаться, поцеловаться с ними...»

Владимир Раевский старался не обмануть надежд, возлагаемых на него отцом. Будучи зачисленным в 1811 году после окончания пансиона в Дворянский полк при 2-м кадетском корпусе в Петербурге, он проявлял похвальное прилежание к военным наукам, добросовестно штудировал труды прославленных русских полководцев, особенно А.В. Суворова. В этот период у него начинает пробуждаться осознание социальной несправедливости существующих в России порядков. Раевского-дворянина тяготило угнетение народное... Он писал о том, что помещики, заставляя крестьянина работать и в выходные дни, отлучают его от церкви, подрывают нравственные устои общества. По его словам, «сея семена змееядные», власть имущие пожнут горькие плоды. Так и случилось.

«Один в поле не воин», - гласит русская пословица. Но Владимир Федосеевич оказался именно таким одиноким борцом с ударами судьбы. Горькому одиночеству посвящены строки стихотворения «Песнь невольника», созданного в начале $1820-$ х годов:

Пенаты добрые, отчизны берег милый, Поля родимые, где в юности счастливой Мой век с беспечностью покойно, мирно тек;

Простите навсегда! Окованный цепями, 


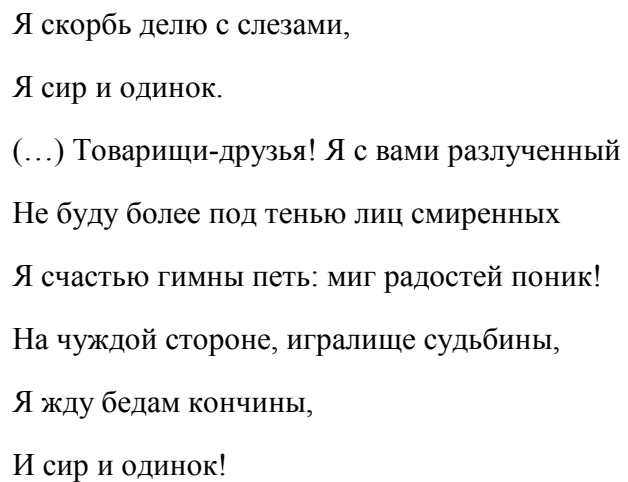

Но жалобы на судьбу - это удел лирического героя стихотворения. Сам же Раевский в любых, самых сложных жизненных перипетиях оставался гордым, не покорившимся, не опустившим головы воином. Он ни разу не позволил себе уныния, смирения и прекращения борьбы. Ни на Бородинском поле в 1812 году... Ни 5 февраля 1822 года при аресте генералом Сабанеевым, о котором он в своих «Воспоминаниях» писал: «Этот роковой час 12-й решил участь всей остальной жизни моей. Мне был 27-й год. Этим арестом кончилась моя светлая, общественная жизнь - началась новая, можно сказать, подземная, тюремная. После жизни военной и тюремной... началась жизнь ссыльная»... [6] (Захар Прилепин). Ни при объявлении приговора о взыскании тысячи семисот шестнадцати рублей и четырёх копеек, истраченных на прогоны в связи с судебным процессом и «лишении живота», - приговора, который он смог опротестовать... Ни в ссылке, оказавшись вдали от остальных декабристов, которые, как могли, поддерживали друг друга, получая помощь от родственников... Ни во время последней поездки в отчий дом для получения своей доли наследства, на которое он, как оказалось, уже не смог претендовать, потому что оно было растрачено неразумным управлением брата Петра и поделено между замужними сёстрами, не пожелавшими помочь старшему брату... 
Большую роль в формировании личности В.Ф. Раевского сыграли события Отечественной войны 1812 года. Оказавшись на Бородинском поле, Раевский не думал о грозящей опасности, у него было одно стремление: победить, разгромить врага. Вот что писал он впоследствии о своих переживаниях на поле битвы: «О собственных чувствах я скажу только одно: если я слушал вдали гул пушечных выстрелов, тогда я был не свой от нетерпения, и так бы и перелетел туда... Полковник это знал и потому, где нужно было послать отдельно офицера с орудиями, он посылал меня» [5] (Натан Эйдельман). В послужном «формуляре» краткая запись: «26 августа участвовал в сражении под селом Бородино, за отличие в коем награждён золотою шпагою с надписью «За храбрость». Молодой артиллерист проявил себя и как талантливый поэт. Его стихи по сути своей публицистичны, они призывают на борьбу за свободу и счастье Родины. Патриотические мысли и чувства Раевского ярко выражены в стихотворении «Песнь воинов перед сражением», написанном в разгар войны:

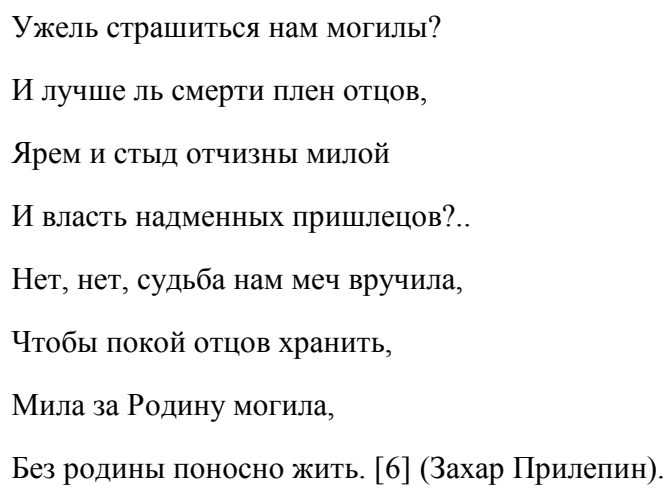

Если бы не рок судьбы, не стремление бороться за справедливость, Владимир, судя по его мужеству перед лицом смерти, легко смог бы сделать военную карьеру. Однако же мировоззрение Владимира Федосеевича свидетельствовало о неприятии им военных действий. «Война, - считал 
Раевский, - это страшное преступление против человечества, а её зачинщики преступники, которых надо судить народным судом. Я бы спросил, - писал он в заметках о войне 1812 года, - что чувствовал Наполеон, когда после Бородинского сражения 40 тысяч трупов и раненых, стонущих и изнемогающих людей густо покрывали поле, по которому он ехал?... Почему человека, гражданина за убийство одного такого же гражданина наказывают смертию... а смертоубийство массами называют победою?» Несправедливая война, и вообще война, если её можно избежать договорами, уступками, должна рассматриваться судом народным, и виновников такой войны предавать суду и наказывать смертию. Тогда войны были бы реже - и сотни тысяч людей молодых, крепких и здоровых уцелели бы от насильственной смерти». Эти слова звучат актуально и в наши дни.

Противник войны, Раевский так и остался в чине майора. После службы в Каменец-Подольском, где он создал свободолюбивый офицерский кружок «Железные кольца», члены которого носили в знак «священной» дружбы особые железные кольца - символ политического союза, Владимир Федосеевич в конце 1817 года в знак протеста против жестоких наказаний в армии подал в отставку и возвратился домой. Прожив в Хворостянке полгода, он в звании штабс-капитана поступил в 32-й егерский полк, где создал тайное сообщество единомышленников под названием «Дружеский лист». Во время службы в 32-м егерском полку Раевский близко познакомился с видными членами тайного общества М.Ф Орловым и А.Г. Непениным, вступил в «Союз благоденствия», где его соратниками стали будущие декабристы П.И. Пестель, Г.С. Волконский.

Владимир Федосеевич обладал незаурядными организаторскими и педагогическими способностями. Генерал Орлов в августе 1821 года назначил его начальником дивизионного учебного заведения в Кишинёве. Здесь майор Раевский преподавал слушателям историю, географию, государственное 
право. На уроках литературы давал юнкерам задания заучивать наизусть стихотворения К.Ф. Рылеева, К.Н. Батюшкова, В.А. Жуковского, выбирая те, которые имели политическую направленность. На занятиях он ввёл собственноручно сделанные прописи, в которые вставил слова «свобода», «конституция», «равенство», «революция». Разъяснял солдатам, что природа создала всех людей одинаковыми и поэтому между нами должно быть равенство. Политическая пропаганда была положена и в основу педагогической деятельности Раевского в ланкастерской школе - школе взаимного обучения солдат. Поэтому чрезвычайно важна та характеристика «духа армии», которую дает Раевский позже в своих «Воспоминаниях». Говоря о намерении Тайного общества произвести «военную революцию», Раевский пишет: «На 2-ую Армию можно было смело рассчитывать <... Солдаты в 16-й дивизии готовы были на отчаянное дело. Именно в этой атмосфере возник такой памятник декабристской публицистики, как политическая записка Раевского «О солдате», проникнутая духом идей тайного общества

Несмотря на то, что именно эти занятия послужили косвенной причиной ареста, заключения в тюрьму и ссылки, Раевский никогда не сожалел о содеянном. Более того, находясь в ссылке, снял помещение и для распространения грамотности среди крестьянских детей создал школу в далёкой сибирской деревне. В Олонках, где он отбывал ссылку, даже женатые стали ходить в училище. Раевский обладал удивительным талантом располагать людей к себе, поэтому сумел сблизиться с простым народом, женился на крещёной бурятке Евдокии Моисеевне Середкиной (1.03.181122.04.1875), крестьянке села Олонки Идинской волости Иркутской губернии, родившей ему девятерых детей. Успешно работал от крестьянского общества по поставке чая и вина, хлебопашествовал, огородничал: устроил парники, выращивал арбузы и дыни; купил мельницу, завел лошадей; крестьянское 
общество поручило ему, как грамотному и умелому человеку, вести общую торговлю.

В Сибири он продолжал писать стихи, среди которых особого внимания заслуживает одно из самых сильных, выношенных и выстраданных его произведений — стихотворение «Мой милый друг, твой час пробил», известное под названием «К дочери» (1848). Обращенное к старшей дочери поэта и приуроченное к ее замужеству, оно имеет и более широкий адрес. Это обращение к молодому поколению, которое должно правильно оценить сделанное отцами, сберечь и продолжить их дело. Раевский возвращается памятью к дням молодости, когда он «боролся долго» «с разъяренными волнами», к грозному часу, когда над ним «гром ударил в тишине». Он не признает справедливости обрушившейся на него кары. Он зовет новых людей на святой подвиг, на то, чтобы «гореть к высокому любовью», бороться так же самоотверженно, как отцы. В центре творчества Раевского — образ «певца в темнице», непреклонного борца за свои идеалы, не склонившего «рамен с главою» ни перед людьми, ни перед судьбою. Вопреки всем ударам рока, отсутствию помощи и поддержки в сложных жизненных ситуациях В.Ф. Раевский не пал духом, остался верен себе, своим идеалам и ценностям до конца.

Свидетельством неординарности личности В.Ф. Раевского является тот факт, что за недолгое время общения в Кишинёве с А.С. Пушкиным Владимир Федосеевич сумел завоевать доверие и уважение великого русского поэта. По свидетельству И.П. Липранди, изложенному в работе П.Е. Щеголева, «Пушкин, как вспыльчив ни был, но часто выслушивал от Раевского, под весёлую руку обоих, довольно резкие выражения и далеко не обжался, а напротив, казалось, искал выслушивать бойкую речь Раевского». Оба поэта относились друг к другу с известной долей иронии: Раевский называл Пушкина «Овидиевым племянником», а Пушкин прозвал сурового к себе и 
другим Раевского «Спартанцем» за смелость его политических суждений. Именно Пушкину судьба доверила первым узнать и предупредить Раевского о грядущем аресте, он дал товарищу возможность уничтожить некоторые компрометирующие материалы. На следующий день после их беседы, 6 февраля 1822 года, Раевский был взят под стражу и заключен в Тираспольскую крепость. Пушкин тяжело переживал случившееся. Поэтузник сумел передать из крепости стихотворение-послание «Друзьям в Кишиневе». Там были строки, обращенные к Пушкину, «певцу Кавказа».

\author{
Оставь другим певцам любовь! \\ Любовь ли петь, где брызжет кровь, \\ Где пламя чуждое с улыбкой \\ Терзает нас кровавой пыткой, \\ Где слово, мысль, невольный взор \\ Влекут как явный разговор, \\ Как преступление, на плаху.
}

Прочитав это стихотворение, Пушкин сказал: «После таких стихов не скоро же мы увидим этого Спартанца!» И действительно, после ареста Раевского им больше встретиться не пришлось. В наследии Пушкина есть три незаконченных ответа на послания к нему поэта-декабриста Раевского: послание «Ты прав, мой друг, напрасно я презрел» и стихотворения «Свободы сеятель пустынный», «Не тем горжусь я, мой певец».

Владимир Федосеевич был мужественным и остроумным, смело выражал свою точку зрения. Одно из его неосторожных высказываний и привело к замене почти оправдательного приговора на ссылку в Сибирь, но в этом был весь Раевский. Великий князь Михаил Павлович поинтересовался, где Раевский получил образование, и пренебрежительно отозвался об университетах и пансионах как рассадниках смуты. На что Раевский ответил: 
«Пугачёв не учился ни в университете, ни в пансионе». Следственному комитету так и не удалось доказать причастность майора Раевского к делу декабристов, поднявших восстание в Петербурге и на Юге, однако это не помешало сурово наказать его за упорство и вольнодумство.

История, как известно, движется по спирали. В ходе исследования выяснилось, что нелёгкой была судьба не только первого декабриста, но и его потомков. Из книги Натана Эйдельмана «Первый декабрист», где он цитируется автобиографическая повесть А. Жигулина «Черные камни», удалось узнать, что 1 января 1930 года родился Анатолий Жигулин, праправнук В.Ф. Раевского; в будущем, как и предок, - он заговорщик и поэт. Детство и юность его проходят в Воронеже, где в 1947-1948 годах создается Коммунистическая партия молодежи. В нее входило более пятидесяти человек, в том числе и Анатолий Жигулин, часто действующий под фамилией Раевский. Цель организации - «изучение и распространение в массах подлинного марксистско-ленинского учения». В сентябре 1949-го ЖигулинРаевский арестован и отправлен в ссылку: из Воронежа через Москву (в фургоне «Мясные изделия»), в столыпинских вагонах - через Россию и Сибирь. В сентябре 1950-го - августе 1951-го - тайшетская пересылка, тяжелая работа на лесоповале, где однажды возникает диалог:

- Раевский? Вы дворянин?

- Нет. Мама была дворянкой.

- Позвольте, но ведь Раевских-мужчин, кажется, всех перебили во время гражданской войны, оставшихся - в тридцать седьмом. Вы старший сын в семье?

- Да.

- Так вы, Толя, по законам Российской империи, потомственный дворянин. Ибо если пресекается мужская линия знаменитых наших 
фамилий, то титул и звание наследует старший сын женщины, принадлежащей к этому роду. А у вас еще и фамилия двойная.

В августе - сентябре 1951-го отправка из Тайшета на Колыму; затем три каторжных года. Только в 1954-м году, после годов тяжелейшей работы на лесоповале и пыток Жигулина амнистируют. Он, так же, как и прапрадед, не мог молчать. История его непростой судьбы вылилась на страницы литературных произведений: поэтических сборников и автобиографической повести «Чёрные камни».

\section{Заключение}

Таким образом, исследование подтвердило гипотезу о том, что в судьбах людей, борющихся против существующего миропорядка за справедливость, стремящихся улучшить облегчить жизнь других людей, тесно переплетаются героизм и трагизм. В.Ф. Раевский достоин сохранения памяти о нём: вопреки сложнейшим ситуациям, создаваемых для него судьбой, бесконечным испытаниям на прочность, Владимир Федосеевич до конца своих дней продолжал трудиться и преумножать добро в нашем сложном и подчас горестном мире.

\section{Литература}

1- Ермолаева Полина. Здесь кольбель твоя была... nsportal.ru/ap/library/ literaturnoe-tvorchestvo/20...s-kolybel-tvoya-byla 08.02.2018г.

2- Жигулин А. (1988). Черные камни. Москва: Изд-во «Журнал "Знамя"» № 7 и 8.

3- Захар Прилепин. За нами горы тел кровавых. www.reading-hall.ru/ publication.php?id=19543 08.02.2018г.

4- Крупенков А.Н. (1992). Братья Раевские. Белгород: Изд-во «Везелица».

5- Крупенков А.Н., Крупенков Н.Ф. (1994). Судьба декабриста: Историческое повествование. - Белгород: Изд-во МП «Квант».

6- Натан Эйдельман. Первый декабрист. vivovoco.astronet.ru/VV/PAPERS/NYE/ FIRST/DEC01.HTM 08.02.2018г. 
7- Раевский В.Ф. Из литературного наследия В.Ф. Раевского. Воспоминания В.Ф. Раевского. docplayer.ru/26336073-Iz-literaturnogo-naslediya-v...a-v-fraevskogo.html 08.02.2018г.

\section{Bibliography}

1- Ermolaeva Polina. Zdes' kolybel' tvoja byla ... nsportal.ru/ap/library/literaturnoetvorchestvo/20...s-kolybel-tvoya-byla $08.02 .2018 \mathrm{~g}$.

2- Zhigulin A. (1988). Chernye kamni. Moskva: Izd-vo «Zhurnal "Znamja"» № 7 i 8.

3- Zahar Prilepin. Za nami gory tel krovavyh. www.readinghall.ru/publication.php?id=19543 08.02.2018g.

4- Krupenkov A.N. (1992). Brat'ja Raevskie. Belgorod: Izd-vo «Vezelica».

5- Krupenkov A.N., Krupenkov N.F. (1994). Sud'ba dekabrista: Istoricheskoe povestvovanie. - Belgorod: Izd-vo MP «Kvant».

6- Natan Jejdel'man. Pervyj dekabrist. vivovoco.astronet.ru/VV/PAPERS/NYE/FIRST /DEC01.HTM 08.02.2018g.

7- Raevskij V.F. Iz literaturnogo nasledija V.F. Raevskogo. Vospominanija V.F. Raevskogo. docplayer.ru/26336073-Iz-literaturnogo-naslediya-v...a-v-f-raevskogo .html 08.02.2018g.

HOW TO CITE THIS ARTICLE

Юнкина A. A. (2020). A Reflection of the Struggle for Individual Freedom in Nineteenth-Century Russia in the Life and Work of V.F. Raevskogo "The First Decembrist». Issledovatel'skiy Zhurnal Russkogo Yazyka I Literatury, 8(1), 199-216.

DOI: $10.29252 /$ iarll.15.199

URL: http://www.journaliarll.ir/index.php/iarll/article/view/116 
IV Tكيدهاى فارسى

بازتاب مبارزه براى آزادى فردى در روسيه سده نوزدهم

در زندگى و آثار ادبى و. ف. رايفسكى - (اولين دكابريست)

آنّا آلكساندروونا يونكينا'

معلم زبان وادبيات روسى، مدرسهُ آموزش متوسطة شماره لا شهر ستاريى آسكل (ستاريى آسكل اوبلاست)،

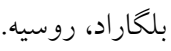

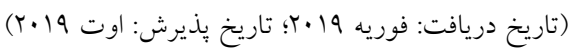

هدف از يزوهش حاضر، بازآفرينى تصوير شخصيت ترازيك و قهرمانانئ شاعر دكابريست يعنى رايفسكى از طريق تجزيه و تحليل كتابهايى است كه به سرنوشـت وى اختـصاص دادئ داده شده است.

ترازدى زندكى رايفسكى در آن است كه دادكاه نظامى او را به جرم آزادانديـشى بــه اعـدام

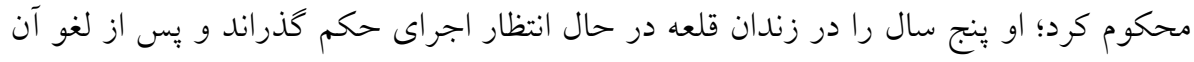

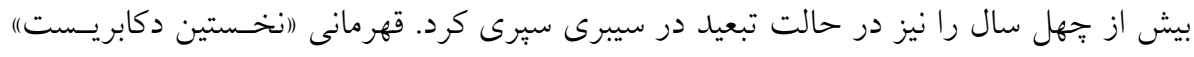

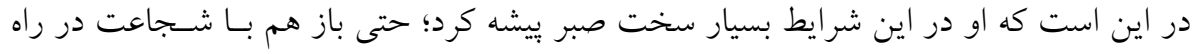

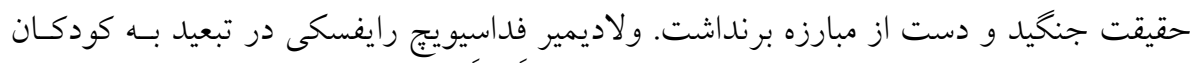



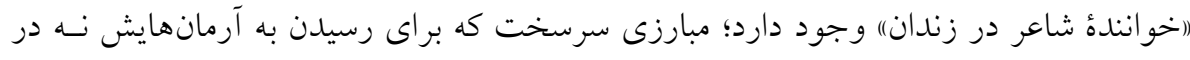

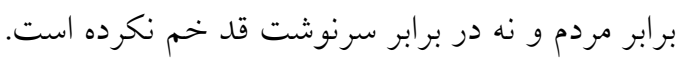

وازگًان كليدى: و. ف. رايفسكى، دكابريست، تبعيد، اشعار، خاندان دربارى، كـار تعلـيم و تربيـت، 